\title{
腹腔鏡手術が困難であった子宮広間膜後面に着床した腹膜妊娠の一例 A case of peritoneal pregnancy implanted at posterior broad ligament of the uterus
}

九州大学医学部附属病院産科婦人科

\author{
梅崎美奈、江上りか、大塚未砂子、安藤文隆、野崎雅裕、中野仁雄
}

\section{緒＼cjkstart言}

子宮外妊娠の頻度は過去30年間に諸外国で増加 傾向にある米国統計センターの報告では、1970年 の子宮外妊娠症例数は 17,800 例で、1989年には

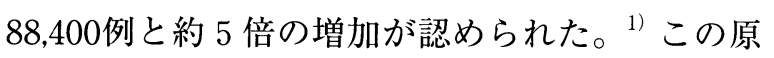
因として性行為感染症による骨盤内炎症の増加に 伴う卵管癒着、体外受精・胚移植 (IVF-ET) に 代表される生殖補助技術（ART）の普及などが 考えられている ${ }^{2)}$ 。子宮外妊娠の中でも腹膜妊娠 は非常に稀であり、その着床部位としてはダグラ 又窩腹膜や腸間膜、大網などが報告されている。 今回、腹腔鏡手術が困難であった右広間膜後面に 着床したと考えられる腹膜妊娠を経験したので報 告する。

症例

32 才、経妊 3 回、経産 1 回。

家族歴：特記すべき事なし。

既往歴：小监期より気管支喘息（最終発作は 20 才)。

21才時に左卵管妊娠で左卵管切除術。

月経歴：初経16才、周期 30 日型、整順、持続 7 日 間。

妊娠分婏歴：16才人工妊娠中絶術。

21 才左卵管妊娠で左卵管切除術。

30才子宮卵管造影で右卵管疎通性不 良と診断され体外受精を行い妊娠、 正常満期産。

現病歴：D年 4 月 5 日から 7 日間を最終月経と して無月経となり、 5 月 12 日より右下腹部痛が持 続するため 5 月18日（最終月経より 6 週 1 日）前 医を受診した。尿中hCGは8,000IU/1であり。経 腟超音波断層法で子宮内に胎囊像を認めなかっ
た。 5 月21日（最終月経より 6 週 4 日）の尿中 hCGは16,000IU/1、経腟超音波断層法で子宮内に 胎囊像を認めず、同日子宮外妊娠の疑いで当科を 紹介受診した。当科外来での経腟超音波断層法で 子宮内に胎囊像を認めず、右付属器領域に無エコ 一領域を認めたため、子宮外妊娠（右卵管妊娠疑 い）と診断し、精查加療目的で当日入院となった。 入院時所見：身長 $151 \mathrm{~cm}$ 、体重 $43 \mathrm{~kg}$ 、体温 $36.4^{\circ} \mathrm{C}$ 、 血圧 $124 / 74 \mathrm{mmHg}$ 、脈拍 $90 / \mathrm{min}$ 。外子宮口から の出血はなく、子宮は前傾前屈、超鶏卵大であっ た。両側付属器を触知せず、圧痛を認めなかった。 直腸診でも異常を認めなかった。経腟超音波断層 法では、子宮内に胎囊像を認めず子宮体部内膜の 厚さは $11 \mathrm{~mm}$ であった。左卵巣は $21 \mathrm{~mm} \times 12 \mathrm{~mm}$ と同定できたが、右卵巣は同定できなかった。子 宮と連続した右付属器領域に $45 \times 27 \mathrm{~mm}$ の高輝度 エコー像の中に径 $19 \mathrm{~mm}$ の低輝度エコー像を認め 胎囊と考えられた（図 1)。胎児様エコー像は認 めなかった。ダグラス窩に少量の腹水と考えられ る51×12mmの無エコー領域を認めた。ダグラス 窩穿刺を施行し、非凝固性血液 $5 \mathrm{ml}$ 採取した。 入院時検查所見：一般検血では、白血球数7,800/ $\mu \mathrm{l}$ 、赤血球数 386 万 $/ \mu 1$ 、血色素量 $10.6 \mathrm{~g} / \mathrm{dl}$ 、へ マトクリット $31.8 \%$ 、血小板数 18.3 万 $/ \mu$ と軽度 の貧血を認めた。血液生化学所見では異常所見は なかった。また、尿中hCGは16,000IU/1、血中 $\mathrm{hCG} 155,700 \mathrm{mIU} / \mathrm{ml}$ であった。血中抗クラミジ ア抗体はIgG陽性（インデックス6.19）、IgA陰性 （インデックス0.37）であった。

術前診断：\#1、妊娠 7 週 0 日

子宮外妊娠。妊娠部位として右卵管ま たは右卵巣または腹膜あるいは勒帯内 妊娠疑い。 


\section{\# 2、貧血。}

図 1 手術前の経臸超音波断層法

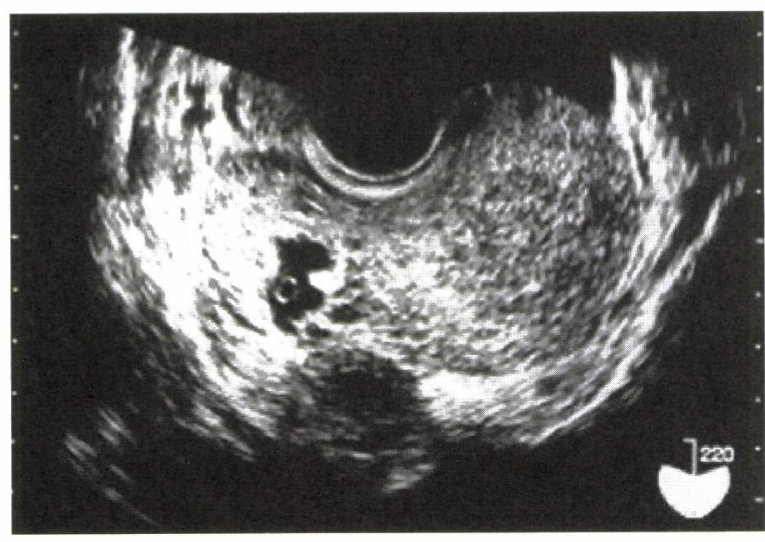

卵黄囊構造を含む腫瘤像

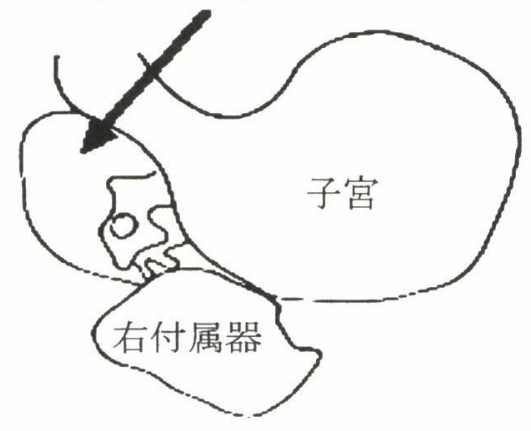

手術所見：上記の術前診断で 5 月24日（7 週 0 日) 気腹法による腹腔鏡を施行した。腹腔内に少量の 血性腹水を認め、下腹部左側の壁側腹膜と大網が 広範囲に癒着していた。左卵管は切除後の状態で、 右卵管に異常を認めなかった。右卵巣は軽度腫大 しており、小腸と癒着し頭側に偏位しており、癒 着剥離後に膨隆部を切開したところ黄体を認め た。以上より卵管、卵巣妊娠を否定した。さらに 腹腔内を精查すると、右広間膜にやや膨隆した部 分を認め、後葉側を操作子で圧迫すると径約 3 $\mathrm{cm}$ の軟らかい腫瘤状の膨隆があった。中心に径 約 $3 \mathrm{~mm}$ の小孔を認め、操作子での圧迫により極 少量血液が滴下した（図 2 )。腹膜の小孔を一部 開大し、約 $5 \mathrm{~mm}$ 径程度の組織を採取したところ、 絨毛様組織であった。組織摘出後、出血量が増加 乙(図 3 )、止血困難となり、妊娠部位が広間膜 後面である事より開腹操作に変更した。開腹時、 腹腔内に約 $700 \mathrm{~g}$ の出血を認めた。右広間膜後葉 に絨毛成分を伴う出血巣を認め、絨毛成分を一部 残したまま、同部を結紮止血した。術中出血量は $1,000 \mathrm{~g}$ であった。輸血は行わなかった。

経過：術後 7 日目（8週 0 日）の血中hCGは $10,400 \mathrm{mIU} / \mathrm{ml}$ 、尿中 hCGは4,000IU/1で、絨毛遺残 に対しメソトレキセート・ロイコボリン療法を計
図 2 膨隆部圧迫後の広間膜後葉
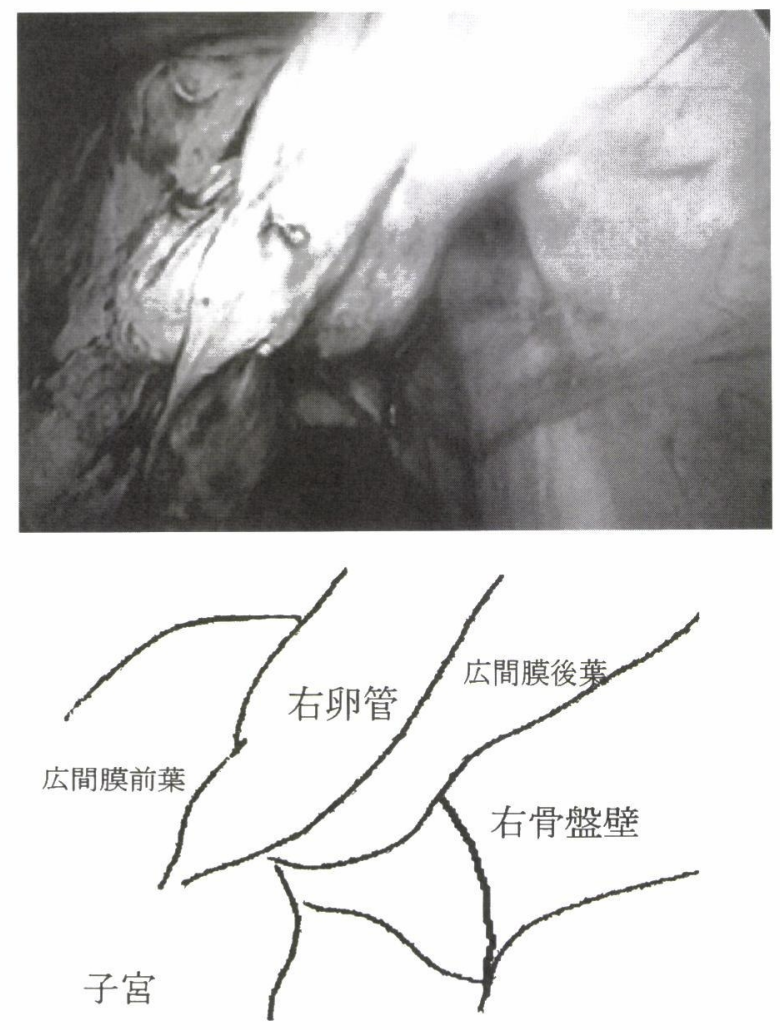

図 3 擮毛採取後の出血
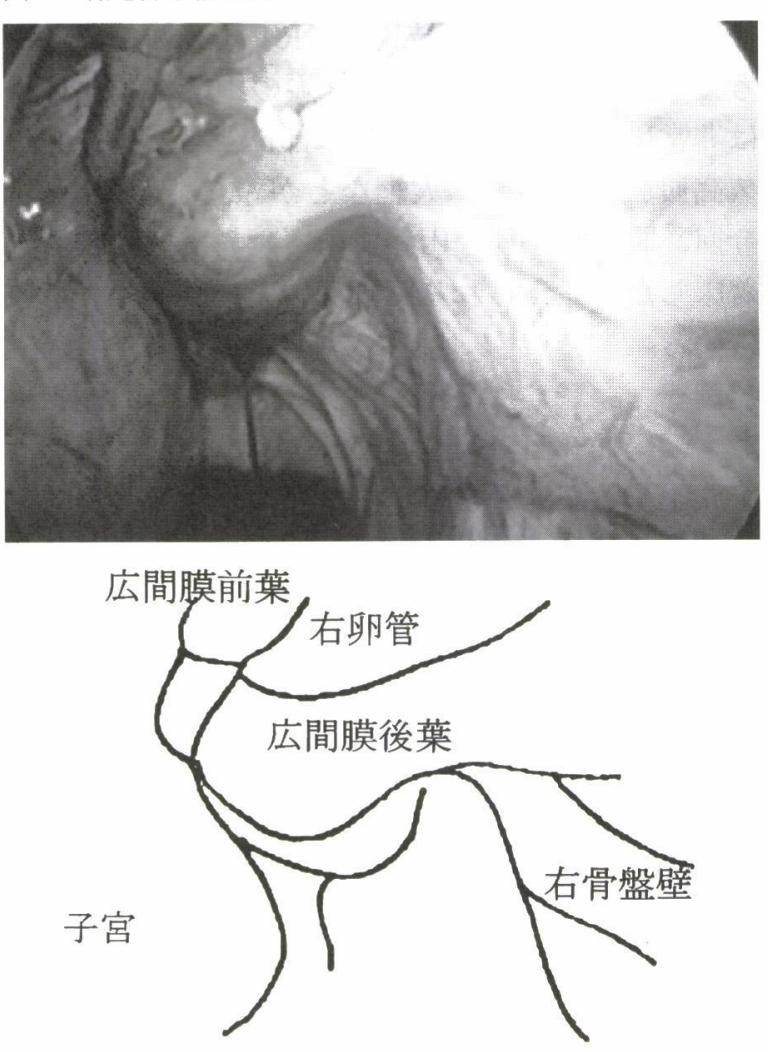

4 回 (メソトレキセートの総投与量は640mg/body) 施行した。経腹超音波ドップラーで右付属器領域 に27×26mmの血流豊富な部分を認めていたが、 7 月 19 日の血中 $\beta-\mathrm{hCG}$ は $0.1 \mathrm{mg} / \mathrm{ml}$ 以下となり 
（表 1）、7 月22日頃には超音波の血流成分を認め られなくなり全身状態良好のため 7 月 27 日退院し

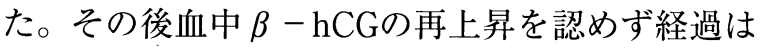
良好である。

表 1 尿中hCG、血中hCG、 $\beta-h C G$

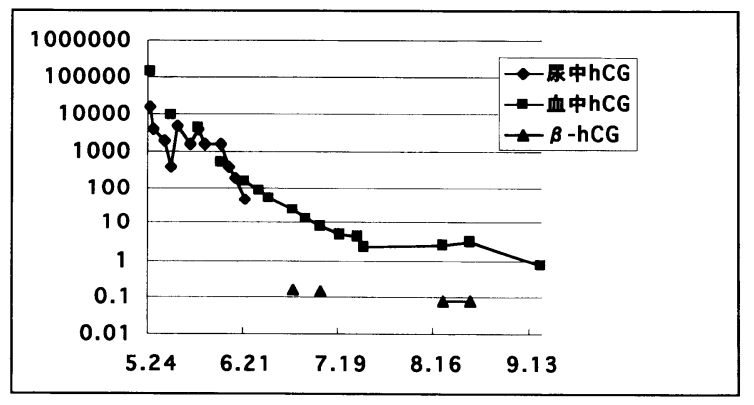

\section{考 察}

子宮外妊娠の発生頻度は全自然妊娠の0.3 $0.7 \%$ 程度と言われており、その中でも腹膜妊娠 は約 $0.4 \%$ と稀である ${ }^{3)}$ 。腹膜妊娠をおこす危険因 子として、自然流産の回数が多いこと、長期の不 妊症、卵管奇形、付属器領域の手術の既往、骨盤 内炎症の既往、子宮内膜症、卵管 - 腹膜妊娠の既 往、コカイン使用等が挙げられる。 $\left.{ }^{4)}, 10\right)$ 腹膜妊 娠は原発性と続発性に分類されるが、続発性は、 卵管内や子宮内の受精卵が卵管采や卵管破裂部 位、子宮筋層の瘦孔などを通って腹腔内に落下し、 腹膜に着床したものをいう。原発性は子宮や卵 管・卵巣に異常を認めず、妊娠部位であったこと を推察させる所見のないものをいゔ ${ }^{6)}$ 。大部分は 続発性であると言われている 巣・卵管および卵管間膜に異常を認めなかったこ とより原発性であると推察した。

腹膜妊娠は他の子宮外妊娠に比べ死亡率が高い とされるが、妊娠週数の早い時期に診断され妊娠 部位が血管野を含んでいない症例では、腹腔鏡に よる切除術が有効であったという報告がある77,8)。 本症例では術前の経胵超音波断層法で子宮内に胎 囊像を認めず、子宮の右側に偏位して胎囊像を認 めたこと、右卵巣を同定できなかったことから、 子宮外妊娠と診断した。また子宮に近く接してみ えたことから、卵管妊娠としては非典型的な位置 と考え、卵巣妊娠、腹膜妊娠、または勒帯内妊娠 の可能性もあると考えた。結果的には、この子宮 と非常に近く隣接しており筋層と連続しているか のように見えた経腟超音波断層像がもっとも診断 に有用な情報であったと思われる。大網が腹壁に 癒着しており、また右卵巣が小腸と癒着し頭側に
偏位していたために、術前の超音波断層法で右卵 巣の同定は、困難であった。

右広間膜後葉に着床した機序については、受精 卵が右卵管を経て腹腔に落下し着床する可能性 と、精子のみが卵管を通過し腹腔内で受精し腹膜 に着床した可能性の 2 つの腹膜妊娠としての機 序、および卵管が穿孔し妊卵が勒帯内に着床した という勒帯内妊娠としての機序が挙げられる。本 症例では、広間膜後葉に着床した腹膜妊娠と靱帯 内妊娠とを確実に鑑別することは困難である。し かし、鞄帯内妊娠は、ふつう妊卵が卵管を穿孔し 卵管間膜を通過して靱帯内に着床するとされてお $\eta^{6)}$ 、本症例では前述のように卵管に異常を認め ず妊娠部位から卵管までの距離は約 $5 \mathrm{~cm}$ と離れ ていたため、妊娠の機序として卵管が穿孔した可 能性は低いと考え、広間膜後葉への着床による腹 膜妊娠と推察した。また腹膜の小孔直下に絨毛を 採取したことも、より腹膜妊娠とすべき所見であ ると考えられた。

今回の症例で、治療法の選択においてポイント となるであろう点が三点考えられる。まず、第一 に腹腔鏡を行う以前に腹膜妊娠と診断できたか、 第二に腹腔鏡で出血部位らしい小孔を発見したと きに内容に触れずに着床部位と診断できたか、第 三に開腹術に移行した際に絨毛組織を全摘できた かである。第一点については、超音波断層像から だけでは部位を特定することはできなかったが、 術前に胎囊様像が子宮に近く筋層と連続している かのように見えた時点で、骨盤血管造影 (PAG) を施行していれば診断が可能であった可能性もあ る。第二点は最も問題のある点であり、ここで絨 毛採取による大出血の可能性を十分予測していれ ば開腹はせずに化学療法を選択できたと考えられ る。今回、操作子で押して初めて出血を確認でき、 妊娠部位であるとの確信が持てなかったために組 織を一部採取したが、視診により妊娠部位である と確信し安全に全摘できる可能性のある大きさ (後述のように径 $1 \mathrm{~cm}$ 未満が妥当か) でなければ 採取しないという判断も可能であろう。第三点も 妊娠部位の大きさや場所と関連するが、膨隆部位 の径が約 $3 \mathrm{~cm}$ と大きく全摘出を試みれば、さら に出血を来たし、輸血も不可避となったであろう。 また全摘出を試みても絨毛遺残の可能性はある。 Olsenの報告 ${ }^{4)}$ では右勒帯内妊娠の組織を腹腔鏡 下に全摘しており、安全に手術できた理由として 尿管・血管から離れていたこと、妊娠組織が径 1 $\mathrm{cm}$ 未満で小さかったことを挙げている。また 
Moritaらの報告でも妊娠組織の大きさは径 $1 \mathrm{~cm}$ であったとしている。 ${ }^{7)}$ 本症例は径 $3 \mathrm{~cm}$ で止血 困難となったことから、少なくとも径 $3 \mathrm{~cm}$ 以上 の腹膜妊娠や勒帯内妊娠においては腹腔鏡による 保存的外科手術を続行することは、止血を十分に 行えない可能性があるという点で、困難であると 考えられる。

腹膜妊娠の早期診断はしばしば困難であるとさ れている。なぜならば臨床経過、臨床所見、超音 波検査が非特異的であるためである。週数が経過 していれば、経産婦においてはしばしば下腹部不 快感などの前回妊娠時と異なった症状や児の動き によって気付く事もあるとされている。過去 40 年 間に発表された症例の 50 0 90\%が、術前には腹膜 妊娠以外の診断であった。9

表 2 に、稀な子宮外妊娠の部位である靫帯内妊 娠、腹膜妊娠、卵巣妊娠について、文献的知見を まとめた。勒帯内妊娠に関する報告は非常に少な いが、腹膜妊娠は骨盤内炎症の既往や卵巣の位置 の異常と関連があるとされており、今回の症例は、 子宮外妊娠の手術既往があり、骨盤内炎症の既往 および卵巣の位置の異常に該当し、危険群に含ま れるものと考えられた。

\section{表 2 靭帯内妊娠、腹膜妊娠、卵巣妊娠の相違点}

\begin{tabular}{|c|c|c|c|}
\hline & 利带内妊桭 & Do妊极 & 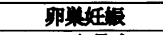 \\
\hline 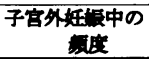 & $0.3 \%(9)$ & $0.4 \%(9)$ & 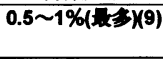 \\
\hline 危调子 & 钯育なし & 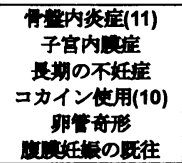 & 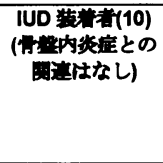 \\
\hline 特糸 & 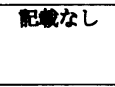 & 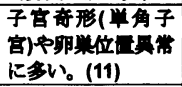 & 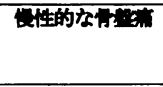 \\
\hline 治漠 & D配なし & 記はし & 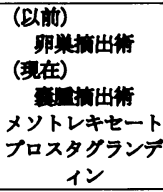 \\
\hline
\end{tabular}

\section{結 語}

我々は非常に稀である広間膜後葉に着床した腹 膜妊娠を経験した。本症例は腹腔鏡で子宮外妊娠 の部位診断を行い、メソトレキセートにより保存 的治療を行った。子宮外妊娠の治療はその部位や 大きさにより、様々な治療法を考慮して決定する 必要があると考えられた。

\section{文献}

1）金井雄二 谷昭博

子宮外妊娠 産科と婦人科 第69号・11号：1526-
15312002 年

2) Cavanagh D.Fla M.

Primary peritoneal pregnancy.

American Journal of Obstetrics \& Gynecology. 76:523-31, 1958

3 ) Pisarska MD. Carson SA. Buster JE.

Ectopic pregnancy.

Lancet.351:1115-20,1998

4) Olsen ME.

Laparoscopic treatment of intraligamentous pregnancy.

Obstetrics \& Gynecology. 89(Pt 2), 1997

5 ) Dover RW. Powell MC.

Management of a primary abdominal pregnancy.

American Journal of Obstetrics \& Gynecology. 172:1603-4, 1995

6 ) Stovall TG. McCord ML:Early pregnancy loss and ectopic pregnancy. In:Berek JS, Adashi EY, Hillard PA, editors.

Novak's Gynecology. Baltimore:Williams \& Wilkens, 1997:485-515

7 ) Morita Y.et al.

Successful laparoscopic management of primary abdominal Pregnancy.

Human Reproduction. 11:2546-7, 1996.

8 ) Ben-Rafael Z.et al.

Laparoscopic removal of an abdominal pregnancy adherent to the appendix after ovulation induction with human menopausal gonadotropin. Human Reproduction.10:1804-5, 1995.

9 ) Ginath S. et al.

Successful laparoscopic treatment of a ruptured primary abdominal pregnancy.

Fertility and sterility 74:601-2, 2000.

10) Audain L. et al.

Cocaine use as a risk factor for abdominal pregnancy.

J Natl Med Assoc May; 90:277-83, 1998

11) Costa SD. Presley J. Bastert G.

Advanced abdominal pregnancy.

Obstetrical \& Gynecological Survey. 46:515-25, 1991 